\title{
Heritagising the Vernacular in a Central European Borderland: Wooden Churches and Open-Air Museums in Upper Silesia
}

\author{
Jerzy Gorzelik
}

\author{
Jerzy Gorzelik, PhD \\ University of Silesia in Katowice \\ Faculty of Humanities \\ Institute of Arts Studies \\ Bankowa 11 \\ 40001 Katowice \\ Poland \\ e-mail: jerzy.gorzelik@us.edu.pl
}

Muzeológia a kultúrne dedičstvo, 2021, 9:1:63-79

DOI: $10.46284 / \mathrm{mkd} .2021 .9 .1 .4$

\begin{abstract}
Heritagising the Vernacular in a Central European Borderland: Wooden Churches and Open-Air Museums in Upper Silesia

This article focuses on how the demand for social and political meanings, generated by nation-building processes and competence between nationalisms in Central Europe, has determined the protection and heritagisation of vernacular architecture. The problem has been analysed using the example of the wooden churches in Upper Silesia - the region contested by Germany and Poland. These monuments gained unprecedented importance as they were believed to testify to ancient architectural traditions and were used to prove the Germanic or Slavic roots of regional culture. The article reveals the evolution of churches' meanings and the ways they have affected the monument protection and functioning of open-air museums.
\end{abstract}

Keywords: vernacular architecture, wooden church, Upper Silesia, open-air museum, nationalism

\section{1) Introduction}

An interest in vernacular architecture, which has been growing in Europe since the mid-nineteenth century, can be perceived-generally speaking-as a reaction to intensive modernisation processes connected with the search for roots both in the past and in the traditional culture. Its essential aspect was, to use Anthony D. Smith's term, "elevation of the people" —of the "folk", who were considered the core of the nation, untouched by foreign influences. ${ }^{1}$ The entanglement of ethnography in the processes of nation-building and of marking the "holy homeland" created favourable conditions for popularising the vernacular architecture, especially in the regions which were the subject of litigation of the contending groups. The need for legitimisation of territorial claims inspired the process of investing these objects with new meanings and, in time, their musealisation. Perceived as the keepsakes of the remote past, they became subject to goals motivated by changing circumstances and in this way they were elevated to the status of heritage. A clear example of such practices is found in the wooden churches of Upper Silesia. German, Polish and-to a lesser extentCzech nationalisms tried — and not only in people's imaginations - to include this region to

${ }^{1}$ SMITH, Anthony D. Chosen Peoples: Sacred Sources of National Identity. Oxford: Oxford University Press, 2003, pp. 34-37. 
their communities. After the Great War it led to the plebiscite, military confrontation and to the division of the disputed territory in 1922.

In his paper delivered in 1930, during the conservators' meeting, Tadeusz Dobrowolski, an art historian, a director of the Silesian Museum (created on the initiative of the regional authorities) and one of the main originators of the Polish cultural policy in the Polish part of Upper Silesia, stated: "For it is beyond question that Polishness of Silesia manifests itself most distinctly in the Silesian dialect and in the wooden architecture". ${ }^{2}$ A central role in the PolishGerman dispute about the character of the region was in this way ascribed to the vernacular linguistic and architectural idiom. This status resulted from an already advanced process of social construction of meanings assigned to the wooden sacral architecture, initiated in the nineteenth century, when the cult of monuments of the past emerged. ${ }^{3}$ The aim of this article is to present this process as a spectacular example of heritagising works of vernacular culture and to show their use for the purpose of political legitimisation. The article also analyses the difficulties accompanying these phenomena which justify the use of the term "dissonant heritage". The social models determining cultural heritage management will be discussed as well.

\section{2) Discovery, valorisation and preservation of Upper Silesian wooden churches before 1918}

An interest in Upper Silesian wooden churches as monuments of the past dates back to the mid-nineteenth century. ${ }^{4}$ At that time in this region, mainly constituting the northern-eastern part of the Prussian Silesian Province, there were around 200 such buildings_-erected as log structures, and often accompanied by post-and-beam towers. In short articles published in the local and Berlin periodicals some of the buildings were dated to the thirteenth century, however - as it turned out with time- the oldest ones were built in the fifteenth century. ${ }^{5}$ It was not at odds with a belief, expressed by many authors, that the structure of the churches is evidence for ancient building traditions, dating back not only to the origins of Christianity but also to the remote, pagan past. ${ }^{6}$

The career of the notion Heimat in Wilhelmine Germany favoured the introduction of the wooden church into the collective memory of the inhabitants of Upper Silesia. Heimat, connecting the individual with the Vaterland, described a unique and intimate tie between humans and the landscape, both natural and cultural. ${ }^{7}$ The wooden church held those two

\footnotetext{
${ }^{2}$ DOBROWOLSKI, Tadeusz. Zabytki sqtuki województwa ślaskiego i ich znaczenie dla nauki. Referat wygłoszony na XV Zjeździe Rady Konserwatorów w Katowicach 10 października 1930 r. Cieszyn: [n.p.], 1930, pp. 4-5.

${ }^{3}$ Gorzelik, Jerzy. Drewniany kościół na Górnym Śląsku jako miejsce pamięci (do 1945 roku). In: Studia Ślaskie. Seria Nowa, Vol. 81, 2017, pp. 49-64.

${ }^{4}$ CUNO, Carl. Zu den Skizzen von den alten Holzkirchen in Syrin, Lubom und Bosatz (bei Ratibor). In: Zeitschrift für Bauwesen, Vol. 2, No. 5/6, 1852, p. 212.

${ }^{5}$ CUNO, Zu den Skizzen..., p. 212; LUCHS, Hermann. Stilbezeichnung und Datierung einiger Kirchen Schlesiens preußischen und österreichischen Antheils. In: Zeitschrift des Vereins für Geschichte und Altertbum Schlesiens, Vol I, No. 2, 1856, pp. 298-303; LUCHS, Hermann. Die oberschlesischen Holzkirchen und Verwandtes (Mit Beiträgen von dem geistlichen Rathe Hrn. Weltzel und dem Vic.-Amts-Rathe Hrn. Knoblich). In: Schlesische Provinzial-Blätter (Rübezahl), Vol. 75/ N.S. 10, No. 3, 1871, pp. 109-121.

${ }^{6}$ STRZYGOWSKI, Josef. Die altslavische Kunst. Augsburg: Filser, 1929, pp. 217-258; DOBROWOLSKI, Tadeusz. Najstarsze drewniane kościoly ślaskie jako znaki zamierzchtej przeszłości. Katowice: Instytut Śląski, 1946, pp. 16-17.

7 SPEITKAMP, Winfried. Die Verwaltung der Geschichte. Denkmalpflege und Staat in Deutschland 1871-1933. Göttingen: Vandenhoeck \& Ruprecht, 1996, pp. 36-44.
} 
aspects together, making an example of such artifacts which could be acknowledged, due to their unique qualities, as elements of a natural environment. ${ }^{8}$ This category of objects was highly valued by Erich Rudorff, one of the ideologists and creators of Heimatschutzbewegung, the homeland protection movement. At the turn of the twentieth century one of the most frequently stressed qualities of such buildings was their picturesqueness, resulting from their vivid interaction with landform features and the trees surrounding the buildings. This aesthetic aspect of the vernacular architecture created favourable conditions for inspiring impulses for the renewal of artistic language. But the ethical aspect was equally important for their positive reception. Jean Jacques Rousseau and Johann Gottfried Herder already perceived the idealised life of "noble savages", life that went in accordance with the rhythm of nature, as a moral pattern. A dynamic development of folk studies in the nineteenth century was closely connected with a belief about the "authenticity" of the culture of country dwellers, untouched by technological civilisation and foreign influences. A large group of national ideologues were convinced that it was in the villages that the national spirit was to be found in its purest form, and where it could be-according to the nationalist demands-revived on the higher level of the historical development. ${ }^{\text {? }}$

Both aesthetic and ethical thought contributed to the interest in the Upper Silesian wooden churches among the circle of Bildungsbürgertum - the main base for the homeland protection movement developing in the imperial Germany. Two conservators of the Silesian ProvinceHans Lutsch and Ludwig Burgemeister-focused their attention on the issue of the wooden sacred architecture both theoretically and practically. The first one-in the inventory of the monuments of the region-admitted that wooden churches, "born from the soul of the folk"

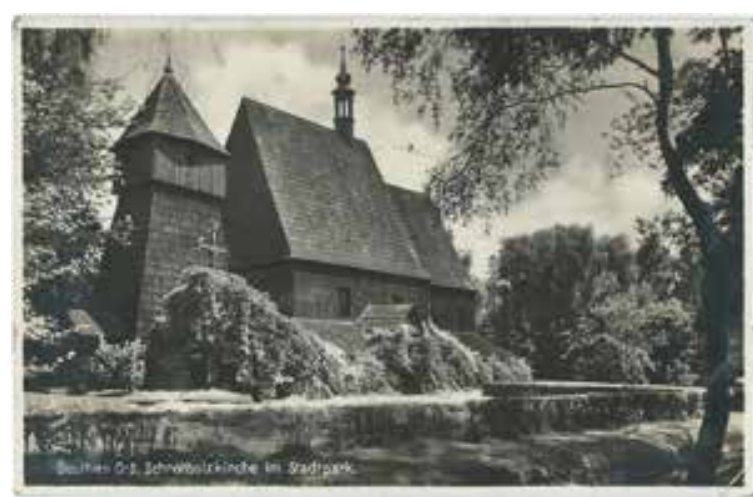

Fig. 1: Bytom, Saint Laurence's Church, relocated from Mikul-csyce, 1940s postcard

Slavic spirit of melancholy, born of a centuries-old tradition of serfdom. ${ }^{11}$

\footnotetext{
${ }^{8}$ SPEITKAMP, Die Verwaltung..., p. 38.

${ }^{9}$ SMITH, Chosen Peoples..., pp. 37-40.

${ }^{10}$ LUTSCH, Hans. Verzeichnis der Kunstdenkmäler der Provinz Schlesien. Bd. IV, Die Kunstdenkmäler des Reg.-Bezirks Oppeln . Breslau: Verlag von Wilh. Gott. Korn, 1894, p. 200; LUTSCH, Hans. Die Dorfkirche. In: SoHNREY, Heinrich (ed.). Kunst auf dem Lande. Ein Wegweiser für die Pflege des Schönen und des Heimatsinnes im deutschen Dorfe. Bielefeld-Leipzig-Berlin: Velhagen \& Klasing, 1905, p. 22.

${ }^{11}$ BURGEMEISTER, Ludwig - Wiggert, Ernst. Die Holzkirchen und Holztürme der preussischen Ostprovinzen. Berlin: Verlag von Julius Springer, 1905, p. 3.
} 
Both conservators perceived saving the wooden churches as a priority, and especially that the monuments were endangered by the modernisation of Upper Silesian villages and by the attitude of the local parish communities striving to replace narrow, rotten buildings with bigger ones, made of bricks or stones. A unique way of protecting buildings was to relocate them to cities-from a small settlement Mikulczyce to Bytom in the Upper Silesian industrial region in 1901 (Fig.1), and twelve years later from Kędzierzyn to Wrocław, the capital of the province. ${ }^{12}$ Both these deconsecrated objects were transferred to city parks where the immediate precincts of the churches were formed in a way that was supposed to repeat or even to enhance the

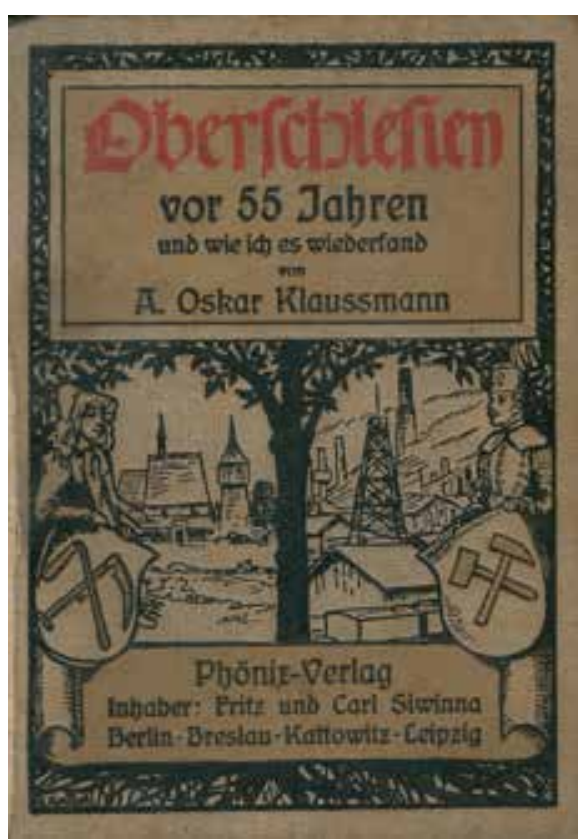

Fig. 2: Anton Oskar Klaussmann's book cover designed by Richard Knötel, 1911

picturesqueness of the original location. In Wrocław, in Szczytnicki Park, the church was placed in the center of the Cemetery Art Exhibition, held as a part of the Centennial Exhibition, aimed at the revival of contemporary crafts by referring to the local traditions. The rearrangement of the building was carried out by the pupils of the local Royal Academy of Arts and Crafts supervised by Fryderyk Pautsch, a Polish painter inspired by the Carpathian folklore. ${ }^{13}$

Both translocations, influenced-according to the declarations of conservation officers-by Scandinavian experiences, were presented as a success, and as evidence of the effectiveness of such a method of preserving the wooden church architecture. ${ }^{14}$ As well as conservators and art historians, artists and their employers also contributed to the process of investing the wooden churches with new meanings conditioned by contemporary needs. In 1904 Emil Nöllner decorated the assembly hall in the Building Crafts School in Katowice (a thriving city in the Upper Silesian industrial region) with paintings presenting monuments emblematic of Silesian architecture from various periods. ${ }^{15}$ Beside three other buildings, there was the church in Mikulczyce accompanied by a Prussian eagle and St. Hedwig of Silesia - a patron of the region. When talking only about Upper Silesia, not about the whole

\footnotetext{
${ }^{12}$ NOWOSIELSKA-SOBEL, Joanna. Od ziemi rodz̨innej ku ojczyźnie ideologicznej. Ruch ochrony stron ojczystych (Heimatschutz) ze szczególnym unzglednieniem Ślaska (1871-1933). Wrocław: Wydawnictwo Uniwersytetu Wrocławskiego, 2013, pp. 322-324; ILKOSZ, Jerzy. „Schlesischer Bund für Heimatschutz” i Wystawa Sztuki Cmentarnej. In: Roczniki Sztuki Ślaskiej, Vol. 16, 1997, pp. 173-182; STÖRTKUHL, Beate. Moderne Architektur in Schlesien 1900 bis 1939. Baukultur und Politik. München: R. Oldenbourg Verlag, 2013, p. 68.

${ }^{13}$ STÖRTKUHL, Moderne Architektur..., p. 68.

${ }^{14}$ Bericht des Provinzial-Konservators der Kunstdenkmäler der Provinz Schlesien über die Tätigkeit vom 1. Januar 1900 bis 31. Dezember 1902 erstattet an die Provinzial-Kommission zur Erhaltung und Erforschung der Denkmäler Schlesiens. Breslau: Druck von Grass, Barth und Comp. (W. Friedrich), 1903, p. 7; Bericht des Provinzial-Konservators der Kunstdenkmäer der Provinz. Schlesien über die Tätigkeit vom 1. Januar 1913 bis 31. Dezember 1914 erstattet an die Provinzial-Kommission zur Erhaltung und Erforschung der Denkmäler Schlesiens. Breslau: Druck von Grass, Barth und Comp. (W. Friedrich), 1914, pp. 3-4.

${ }^{15}$ CHOJECKA, Ewa. A New Polyphony of Art and History. Painting Decoration of the Bolesław Szabelski Auditorium in the Karol Szymanowski Academy of Music in Katowice. In: Revitalization of the Historic Building of the Karol Symanowski Academy of Music in Katowice 1 March 2014 to 30 April 2016. Katowice: Akademia Muzyczna im. Karola Szymanowskiego, 2016, pp. 3-18, accessed 2 April 2020, http://rewitalizacjaeog.pl/images/download/ EOG_AM_aula_album.pdf
} 
Silesian province, the wooden church could serve as the main symbol of regional pre-modern traditions combined with the industrial modernity. A painter, Richard Knötel, designed the cover of a book by a Berlin journalist enthusiastically describing the dynamic development of the eastern peripheries of the Reich (Fig. 2). On this cover the church from Mikulczyce, accompanied by a woman in a peasant dress, was collated with an industrial landscape and a figure of a miner. Both parts of the composition were joined by a motif of a tree with huge roots and a dense crown. ${ }^{16}$ In turn, on a stained glass window in the church in Ligota Bialska designed in 1908 by a Cracow artist, Włodzimierz Tetmajer, a wooden church is presented in the background of the scene with Saints Cyril and Methodius-the "Apostles of the Slavs". This combination of motifs was supposed to indicate the Slavic (i.e. Polish) character of the original culture of the region, announcing the instrumentalisation of vernacular architecture by two contending nationalisms after the Great War.

In spite of the announced success of the translocations, the process of destruction of wooden churches in the first decade of the twentieth century could not be stopped. After erecting new bigger brick and stone churches the wooden objects were excluded from use and they became a burden for parish communities. A provincial conservator, aware of his limited capabilities, listed 21 monuments which needed preservation at all costs and resigned himself to the possible demolition of the remaining ones. ${ }^{17}$ The conflict between those responsible for the protection of the architectural heritage and the local communities who perceived the wooden churches as a burden continued after the First World War and after the division of Silesia, on both the German and Polish sides of the border.

\section{3) The wooden church in the "landscapes of revanchism"}

In the conditions of a bitter ideological argument both sides unequally used the wooden church architecture to impose their own vision of Upper Silesian history. This initially distinct asymmetry resulted from both practical and ideological factors. The strong position of the monument conservation services within the structure of the Polish autonomous Silesian voivodeship enabled them to take actions on a larger scale than those carried out by the conservators in the German Upper Silesian Province. A primordialist concept of the nation (rejected by the part of the German Upper Silesian elites who accepted the right of the individual for self-determination, irrespective of their background or language) created favourable conditions for the use of the wooden church as evidence of an eternal Polishness of the region. In the narrative dominating in the Silesian voivodeship, "Slavic" meant "Polish" but in the narratives of Upper Silesian Province, "Germanic" did not necessarily mean "German". Establishing the continuity between a Slavic past and a contemporary Polishness determined the construction of the meanings of the wooden church by nationalist elites and-as a consequence - an intensive presence of the wooden church in the visual culture of the eastern part of Upper Silesia. It was depicted in the sculptural decoration of the regional parliament, on posters, photos, and in propaganda publications-both those praising the development of

\footnotetext{
${ }^{16}$ KLAUSSMANN, Anton Oskar. Oberschlesien vor 55 Jahren und wie ich es wiederfand. Berlin - Breslau - Kattowitz Leipzig: Phönix-Verlag, 1911.

${ }^{17}$ Bericht des Provinzial-Konservators der Kunstdenkmäler der Provinz Schlesien über die Tätigkeit vom 1. Januar 1903 bis 31. Dezember 1904 erstattet an die Provinzial-Kommission zur Erhaltung und Erforschung der Denkmäler Schlesiens. Breslau: Druck von Grass, Barth und Comp. (W. Friedrich), 1905, p. 9; Bericht des Provinzial-Konservators der Kunstdenkmäler der Provinz Schlesien über die Tätigkeit vom 1. Januar 1907 bis 31. Dezember 1908 erstattet an die Provinzial-Kommission zur Erhaltung und Erforschung der Denkmäler Schlesiens. Breslau: Druck von Grass, Barth und Comp. (W. Friedrich), 1909, p. 77.
} 
the region in the Polish state, and those laying a claim to the part of it remaining within the German borders. ${ }^{18}$

The most ambitious project connected with emphasising the importance of the wooden church and the meanings ascribed to it was the one of establishing an open-air ethnographic museum in Katowice, the capital of the Silesian voivodeship. Here, according to the declarations of the district conservation officer, Tadeusz Dorowolski, the most valuable religious monuments were intended to be placed. ${ }^{19}$ It was supposed to solve the problem of their maintenance costs, as the parishes, which had already built new, brick churches, were unwilling to cover them. At the same time, creating such a museum in Katowice became a part of the policy of Polonisation of this city in which the Prussian times had left a distinct mark, and where the German side won overwhelmingly in the plebiscite.

The idea of establishing open-air ethnographic museums in interwar Poland had a supralocal dimension. Preserving the wooden architecture was perceived as one of the priorities by the conservators who, during the all-Poland convention in 1927, called for the support both of the state and the Roman Catholic church. ${ }^{20}$ Though the Polish experience in this field was

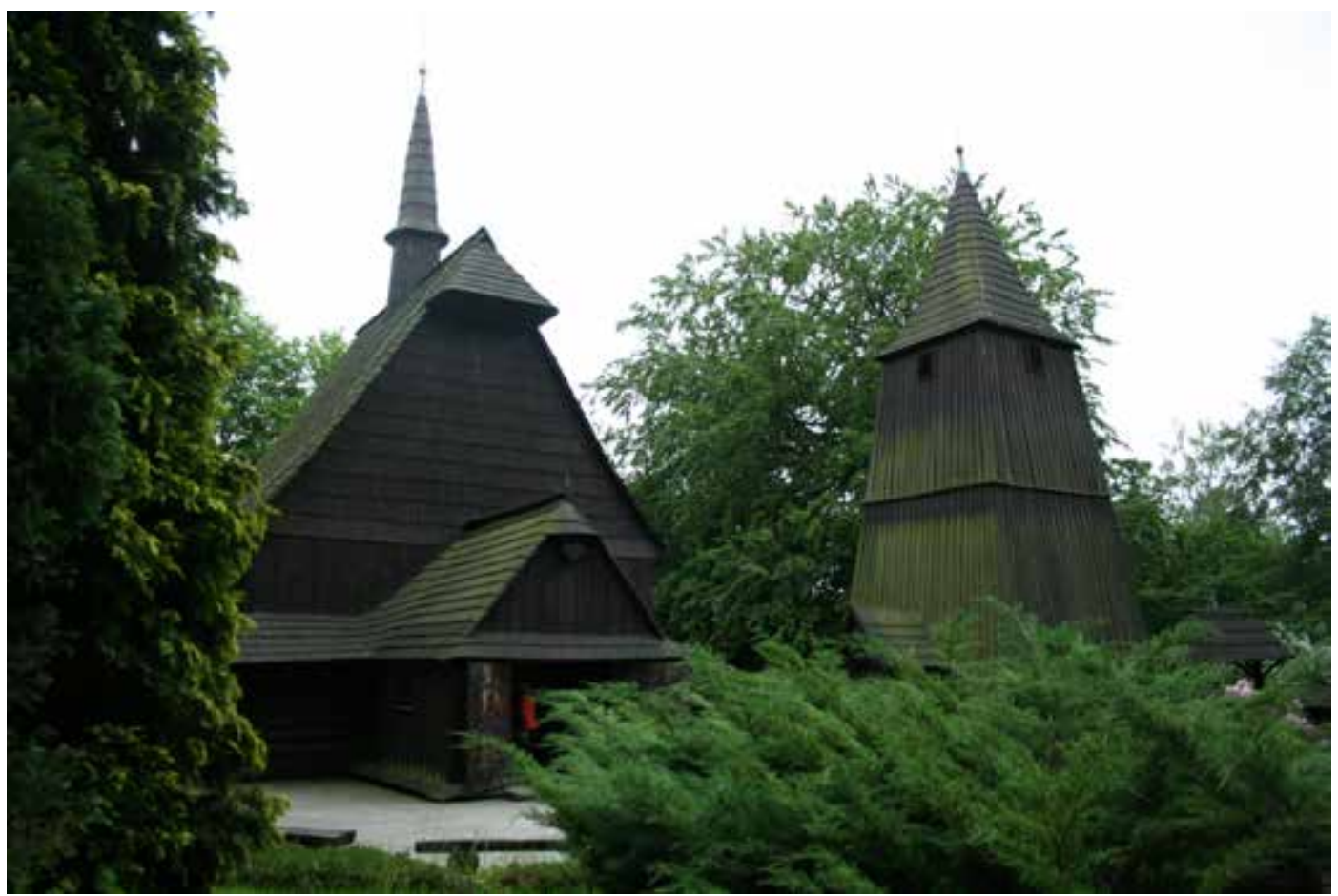

Fig. 3: Katowice, Saint Michael's Church, relocated from Syrynia, photo by Jersy Gorzelike

rather modest, in the new nation state the idea of founding such a museum was well received. There were plans to establish not only a few such regional institutions, but also a central one in Warsaw. Ultimately, during the interwar period only the Museum of Kurpie in Nowogród was

\footnotetext{
${ }^{18}$ GORZELIK, Drewniany kościół..., pp. 58-59.

${ }^{19}$ RYGUS, Piotr. Muzeum na wolnym powietrzu w Katowicach (1929-1955). Idee, plany i realizacja. In: Rocznik Muzeum „Górnoślaski Park Etnografiçny w Chorzowie”, Vol. 1, 2013, p. 87.

${ }^{20}$ II Ogólno-Polski zjazd Konserwatorów w Warszawie w 1927 r. (Uchwały i rezultaty). In: Ochrona Zabytków Sẓtuki. Warszawa: Ministerstwo Wyznań Religijnych i Oświecenia Publicznego, 1930-31, p. 357.
} 
opened, and the first beginnings of the Katowice institution were formed. ${ }^{21}$

The open-air ethnographic museum was placed in a park located in the southern part of Katowice. The park was named after Tadeusz Kościuszko, a Polish hero. Kościuszko was the leader of the first national uprising which, due to the participation of peasants, was presented as a patriotic bid for the independence of the people, similarly to the Polish uprisings in Upper Silesia in 1919-1921. A church transferred in the 1930s from Syrynia (Fig. 3), a village in the southern part of the region, was put in the place of the demolished Bismarck Tower. Thus a modest symbol of an ancient culture of Upper Silesian people (portrayed as homogeneously Polish and Catholic) replaced a massive monument to the Iron Chancellor, an enemy of the Church and Polishness, perceived as an embodiment of Prussian overweening arrogance and German imperialism. The meanings of the vernacular architecture framed by the Polish nationalist discourse were activated during the consecration of the building, which regained its original, liturgical function in the new location. The celebration, with the participation of e.g. the bishop and the mayor of Katowice, was broadcast by the Polish national radio, and the speeches delivered during the ceremony left no doubt that the undertaking had a political character. The mayor described the wooden churches as "the evidence of the eternal affiliation" of Silesia to Poland while the bishop presented them as a proof of the attachment of the Silesian people to Catholicism - "the factor maintaining the patriotic spirit". ${ }^{22}$ In the tale spun

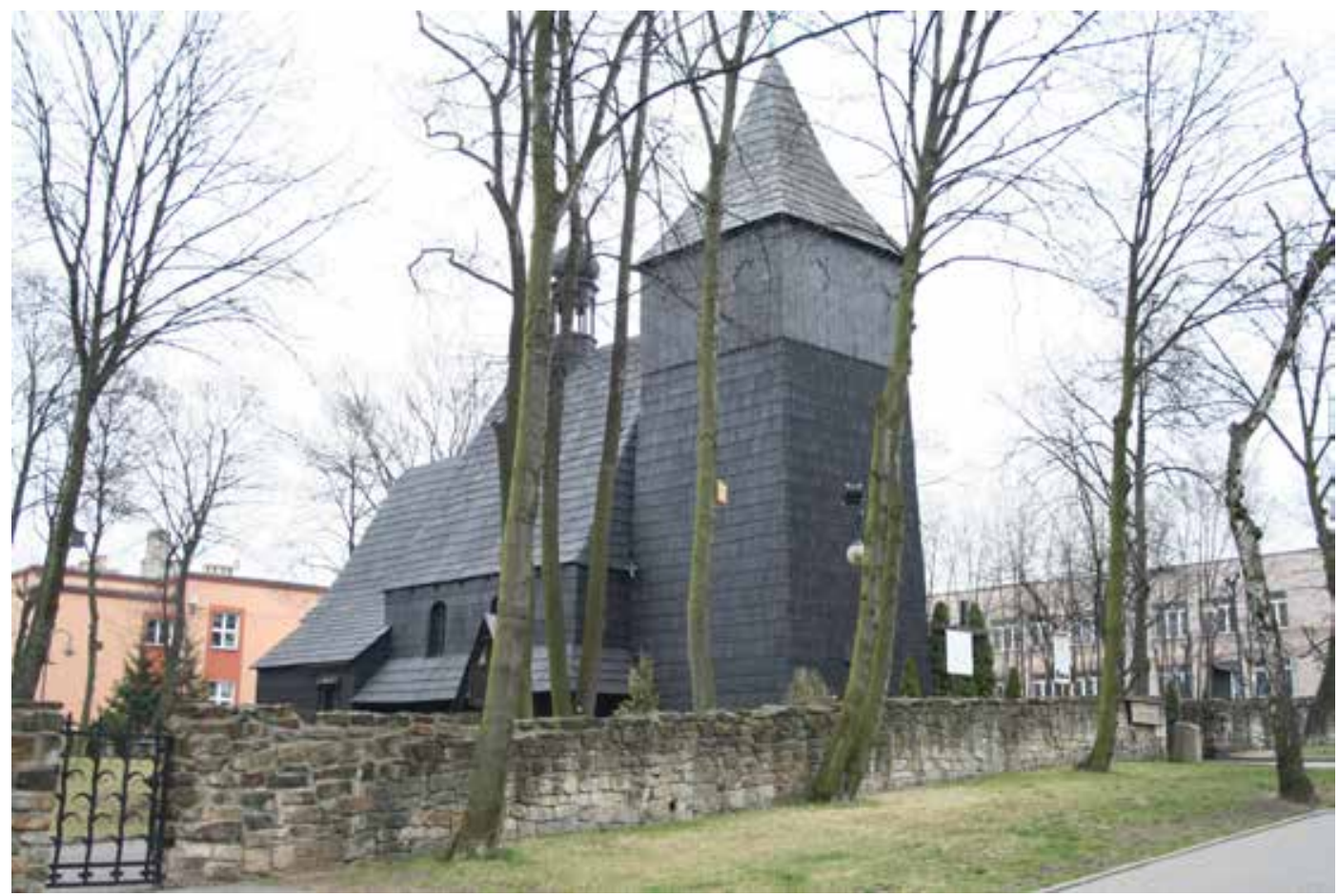

Fig. 4: Chorzón, Saint Laurence's Church, relocated from Knurón, photo by Jeray Gorzelik

by the pro-Polish-oriented Catholic clergy, the Polishness and Catholicism were inseparable and the wooden church assumed the dimension of their bastion. Its image decorated the masthead of a weekly magazine published by the diocese. The aim of the weekly was-apart from the

${ }^{21}$ RYGUS, Muzeum..., pp. 84-85.
${ }^{22}$ RYGUS, Muzeum..., pp. 90-95. 
religious mission — to accomplish the nationalisation of Upper Silesian Slavophones in a Polish spirit.

The outbreak of World War II disrupted the work on the open-air ethnographic museum in Katowice. However-similarly to the above mentioned scenario-in the Silesian voivodeship another translocation of a wooden church took place in the 1930s. A building from a small town, Knurów, was transferred to the second biggest city of Polish Upper Silesia, Chorzów, in which the German minority regularly won the majority of seats in the city council (Fig. 4). As part of a large-scale action of Polonisation, the authorities connected the former Królewska Huta / Königshütte (its name-Royal Iron Works-harking back to the rule of the Hohenzollern dynasty) with its neighboring districts. The entire area was given the Slavic name of one of the districts within it. The hill on which the church was placed, called Mount of Reden (Redenberg) after a Prussian pioneer of industrialisation, was renamed to Mount of Liberation (Góra Wyzwolenia), commemorating the incorporation of the city to Poland. Similarly to the ceremony in Katowice, during the consecration in Chorzów, the Polish character of the building was emphasised, as well as its restoration to its liturgical function. ${ }^{23}$ Both translocations became an opportunity for a tactical cooperation of the public and church authorities. The public authorities, coming from a political camp unpopular among Upper Silesians, which seized power in the country and in the voivodeship by a coup d'état led by marshal Józef Piłsudski in 1926, could symbolically benefit from the support of the Church. The church authorities manifested the vitality of Upper Silesian Catholicism, legitimising their aspirations to play an important part in public life.

In the German part of the region the ideological seizure of wooden churches did not take on comparable proportions in the early post-war years. No greater significance was attached to the use of transferred churches as places of religious worship. In the church located in the City Park in Bytom in the year of the plebiscite (1921), an exhibition of sacral art from a local museum was organised. ${ }^{24}$ Similar plans were considered for the Zembowice village church in which the Gliwice museum was interested. Finally the building was placed in the city, but as a chapel in the new Central Cemetery, where it was consecrated in $1926 .{ }^{25}$ Before national socialists came to power, Upper Silesian wooden churches were a major focus for those who supported the ideas of the Völkisch movement. In 1929 "Der Oberschlesier" magazine published a text by Robert Mielke, an influential cofounder of Bund für Heimatschutz. He described the wooden sacral architecture of the region as a testimony to "Early German construction art" and the key evidence of an eternally German character of Upper Silesia. This opinion gained almost official status during the Third Reich when a symptomatic rearrangement of the church in the park in Bytom was carried out. The majority of the artifacts displayed there were removed and in the middle of the interior there was placed a huge sarcophagus made of coal, crowned with a Stablhelm commemorating those killed in the Great War. Two oaks, named Hitler and

\footnotetext{
${ }^{23}$ POLAK-SPRINGER, Peter. Recovered Territory. A German-Polish Conflict over Land and Culture, 1919-89. New York - Oxford: Berghahn Books, 2018, p. 117; GWIOŹDZIK, Marek - SONTAG, Magdalena. Kościótek św. Wawrzyńca. Światynia i jej dzieje w Knurowie i Chorzowie. Chorzów: Parafia św. Wawrzyńca, 2008, pp. 17-19.

${ }^{24}$ MACHA, Simon. Die Schrotholzkirche auf der Beuthener Promenade, ein kirchliches Museum. In: KASPERKOWITZ Karl - SALOMON D. - STEIN Erwin (ed.). Die deutsche Stadt Beuthen O/S. und ibre nächste Umgebung Monographien deutscher Städte 15). Berlin Friedenau: Deutscher Kommunal-Verlag, 1925, pp. 129-132.

${ }^{25}$ HEINEVETTER, Franz. Die Schrotholzkirche Mariae Himmelfahrt auf dem Hauptfriedhof in Geliwitz. In: Gleiwitzer Jahrbuch. Gleiwitz: Gesellschaft zur Förderung der Stadtbücherei Gleiwitz, 1927, pp. 185-186.
} 
Hindenburg, were planted in front of the church in 1934 on Hitler's birthday. ${ }^{26}$ Turning the object into a place of commemoration of the Kaiser's army soldiers triggered fierce reactions of the Polish side — a weekly published by a radically nationalist Silesian Insurrectionists' Union accused the Germans of an appropriation of the "Polish church", ${ }^{27}$

A new interpretation of the Upper Silesian wooden church in Germany was connected with a "settlement archaeology method" propagated by Gustaf Kossinna. His idea was based on the assumption that clearly defined archaeological cultures should be identified with certain peoples and tribes. ${ }^{28}$ Paradoxically this method-implemented by Kossinna's pupil, Józef Kostrzewski, to demonstrate the continuity of Slavic settlement in the areas between the Odra and Bug rivers since prehistoric times-had earlier influenced the way the wooden architecture was perceived among the Polish intellectuals, who saw in it the evidence of the eternal Polishness of the area. ${ }^{29}$

\section{4) Wooden churches and open-air ethnographic museums in Upper Silesia- from communist to democratic Poland}

The meanings ascribed to Upper Silesian wooden churches by the Polish nationalists were reproduced with an unabated intensity after the shift of the Polish-German border in 1945. A meaningful piece of evidence for this continuity is Dobrowolski's booklet in which he describes the oldest wooden churches in Upper Silesia as reflections of ancient Polish building traditions. ${ }^{30}$ In the 1950 s it was suggested that open-air ethnographical museums be created in both parts of the region: the part belonging to Poland before the war and the part incorporated after the Potsdam Conference. At the same time, systematic research on vernacular architecture in Upper Silesia began. In 1961 the Upper Silesian Ethnographic Park in Chorzów was established, and one year later, the Museum of the Opole Village in Opole-Bierkowice. These two institutions opened in 1975 and in 1970 respectively. In both cases, right from the initial documents, a transfer of a wooden church was planned. ${ }^{31}$ But the tension between the socialist state and the Church became an obstacle to accomplishing this goal. The authorities of the Opole diocese disciplined a parish priest who independently entered into negotiations with the museum, perceiving the unused monument as a burden, while in Katowice diocese the administrator of the building himself tried to convince the episcopal curia to agree on the

\footnotetext{
${ }^{26}$ NADOLSKI, Przemysław. Przedwojenne pomniki Bytomia i jego dzielnic. In: NADOLSKI, Przemysław - WIECZOREK, Edward (ed.). Ze spižu i granitu. Pomniki Bytomia. Bytom: Muzeum Górnośląskie, 2012, pp. 28-29.

${ }^{27} \mathrm{Na}$ Śląsku Opolskim. In: Powstaniec, 1 May 1937, p. 23.

${ }^{28}$ KOSSINNA, Gustaf. Die deutsche Ostmark ein Urbeimatboden der Germanen. Kattowitz: Gebruder Bohm, 1919.

${ }^{29}$ KURNATOWSKA, Zofia - KURNATOWSKI, Stanisław. Der Einfluss nationalistischer Ideen auf die mitteleuropäische Urgeschichtsforschung. In: PISKORSKI, Jan M. - HACKMANN, Jörg - JAWORSKI, Rudolf (ed.). Deutsche Ostforschung und polnische Westforschung im Spannungsfeld von Wissenschaft und Politik. Disziplinen im Vergleich. Osnabrück - Poznań: fibre Verlag / Polskie Towarzystwo Przyjaciół Nauk, 2002, pp. 98-99.

${ }^{30}$ DOBROWOLSKI, Najstarsze...

${ }^{31}$ Archive of the Opole Village Museum (henceforth AOVM), f. Pisma i notatki [Documents and notes], 1958-1971 (henceforth f. Documents 1958-1971), no. 305/4. Bronicz, Stanisław. Założenia dyskusyjne do zagadnienia funkcji planowanego Muzeum Budownictwa Ludowego na Ślasku Opolskim [Debatable principles of functioning of the planned Museum of Folk Architecture in Opole Silesia], 11-12 October 1960; Archive of Upper Silesian Ethnographic Park in Chorzów (henceforth AUSEP), f. Notatki dotyczące opracowania planu koncepcyjnego skansenu śląskiego w Wojewódzkim Parku Kultury i Wypoczynku. Ramowe wytyczne osiedla muzealnego typu skansenowskiego w Wojewódzkim Parku Kultury i Wypoczynku [f. Notes regarding the development of the conceptual plan of the Silesian open-air museum in the Voivodeship Park of Culture and Recreation. Framework guidelines for the museum of the open-air type in the Voivodeship Park of Culture and Recreation].
} 
transfer only if the object kept its liturgical function, or if permission was obtained to build a new church in one of the new housing estates in the industrial district. ${ }^{32}$ The final result was that a church abandoned in 1945, a property of the State Treasury, was acquired by the Museum of the Opole Village. And it was necessary to wait for the political transformation to accomplish the plans in Chorzów. Therefore, despite suggestions in the press during the 1990s, it was not the state that blocked the transfers, but the Church which, unlike in the interwar Silesian Voivodeship, was not interested in cooperation in this field.

Distrust of the state authorities, with whom the Catholic circles disputed over the vision of the national past, in this case outweighed a common aspiration to Polonise the former German lands incorporated in 1945. Such a will was expressed at the very beginning in the planning documents of the Museum of the Opole Village (at first called the Museum of Folk Architecture). Special attention was paid to its "popularising-educational" function due to the necessity of "repolonisation" of ca. 500,000 autochthons inhabiting the voivodeship. Another important goal was the "integrating-assimilative" policy with regard to a similarly large settlement population. An attractive presentation of the "traditionally Polish culture of the Opole village" was supposed to create a platform of a common, unambiguously Polish group identity. ${ }^{33}$ Nationalist goals, expressed in almost every document concerning the planned museum, were complemented by the class elements. The institution was to present a material stratification of the former villages and the "backwardness of the capitalist period". ${ }^{4}$ Similar principles were formulated for the Upper Silesian Ethnographic Park in Chorzów. In one of the studies written for the use of the future institution it was even stated that Prussian building regulations from the nineteenth century preventing continuation of the timber building tradition were only seemingly dictated by fire security factors. In fact, their aim was "an escalation of the terror of Germanisation, fighting with everything connected with Polishness". ${ }^{35}$

In summary, during the Polish People's Republic, the meanings constructed in the interwar period that were ascribed to Upper Silesian wooden churches and applied to the entire wooden architecture of the region were used for the legitimisation of the western state border. They were also used for the autochthons' Polonisation, presented as a return to Slavic roots, and for the authentication of Upper Silesians as the real Poles in the eyes of the settlers from other regions. Even though the establishment and organisation of both Upper Silesian open-air museums became part of the nationwide campaign for creating similar institutions, and these museums were connected with a growing interest in the protection of vernacular architecture

\footnotetext{
32 AOVM, f. Dokumentacja specjalna. Inwentaryzacja - kościół drewniany, Zawada Książęca, powiat Racibórz, no. 302/1. Pismo proboszcza ks. Ewalda Pelki do Wojewódzkiego Konserwatora Zabytków [f. Special records. Inventory - wooden church, Zawada Książęca, Racibórz county, no. 302/1. Letter of a parish priest, Rev. Edward Pelka to the Provincial Conservation Officer], 08 February 1968; Archdiocese Archives in Katowice, f. Akta parafii pw. Trójcy Św. w Leszczynach. Budowy, 1926-1976, no. AL 1139. Pismo proboszcza ks. Wilhelma Dłucika do kurii diecezjalnej [f. Records of the Holy Trinity parish church in Leszczyny. Building, 1926-1976, no. AL 1139. Letter of the parish priest, Rev. Wilhelm Dłucik to the diocesan curia], 29 June 1963.

33 AOVM, f. Documents 1958-1971, no. 305/4. Bronicz, Stanisław. Założenia dyskusyjne do zagadnienia funkcji planowanego Muzeum Budownictwa Ludowego na Śląsku Opolskim [Debatable principles of functioning of the planned Museum of Folk Architecture in Opole Silesia]. 11-12 October 1960.

${ }^{34}$ AOVM, f. Documents 1958-1971, np. 305/4. Bronicz, Stanisław. Materiały do założeń projektowych Muzeum Budownictwa Ludowego w Opolu [Materials for project principles of the Museum of Folk Architecture in Opole], October 1960.

${ }^{35}$ AUSEP, Informacja: Stan realizacji Muzeum Wsi Górnośląskiej (Skansen) w Wojewódzkim Parku Kultury i Wypoczynku w Chorzowie, maj 1970 [Information: completion status of the Upper Silesian Village Museum (Open-air Museum) in the Voivodeship Park of Culture and Recreation in Chorzów, May 1970].
} 
on a European scale, their special functions, conditioned by the character of the region, should not be overlooked.

The political changes of the late 1980s and early 1990s built a base for the new context of the functioning of the wooden church in Upper Silesia. The region has become a new space for different (often competing) memory policies. An official recognition of the German minority meant the necessity to revise an image of a homogeneously Polish land established over the decades. The circles invoking traditions of pre-war Christian democracy combining a moderate Polish nationalism with Upper Silesian regionalism came to the fore in the eastern part of the country, gaining significant influence in the restored local self-governments and designating their own candidate for the post of the provincial governor.

This context should be used to analyse the moving of the wooden church (which regained its liturgical function, similarly to the interwar relocations) to the open-air museum in Chorzów. However, this time the commentaries accompanying the consecration of the building concerned not the national content but a restoration of the proper (from the initiators' point of view) position of religion in the region after its time of being discriminated against by the state authorities. ${ }^{36}$ Therefore the transfer of this monument of sacred art was used to construct a simplified, dualistic picture of the recent history in which the Catholic church played the role of the exponent of the values important for the society.

While the aforementioned translocation complemented the activities undertaken as early as in the 1950s, setting up the Wooden Architecture Route was a brand-new initiative. It was made under an agreement of the self-governments of three voivodeships from southern Poland: the Sub-Carpathian region, Lesser Poland, and Silesia. ${ }^{37}$ Lesser Poland was the leader of the project as since 2003 it had had six wooden churches listed as UNESCO Heritage Sites. According to the agreement, the aim of the Route was the promotion of the voivodeships, the development of cultural tourism, and the protection of the national heritage. Significantly, it was the first cultural route in Upper Silesia - the preparatory works on the Industrial Monuments Route of the Silesian Voivodeship only began in 2004. It was opened two years later and became the main touristic product of the region. Both attempts to create the public heritage are sometimes perceived as competing. This was expressed in the debates conducted by members of the regional assembly when the representative of the national-conservative "Law and Justice" party (PiS) demanded greater care for the Wooden Architecture Route as not only were most of its buildings perceived for decades as evidence of the Polishness of the region, but they were connected with Catholic worship. ${ }^{38}$ The industrial heritage-religiously neutral, and originating mostly under the Prussian and German rule-was a major focus for the regionalists from the Silesian Autonomy Movement. They proclaimed the industrial sites to be testimony to the most spectacular civilisation leap in the region's history. ${ }^{39}$

\footnotetext{
${ }^{36}$ Józef - Robotnik. To nie tylko skansenowa atrapa. In: Dziennik Zachodni, 21-23 June 1996, p. 3; Świątynia znalazła swe miejsce. In: Gość Niedzৃielny, 12 October 1997, p. 16; Brakujący paciorek....In: Driennik Zachodni, 29 September 1997, p. 6.

${ }^{37}$ Powstaje sqlake architektury drewnianej, accessed 2 April 2020, https://www.slaskie.pl/content/386_2002-04-17.

${ }^{38}$ Archive of the Marshal Office of the Silesian Voivodeship, Protokól nr XXVI/12 z XXVI sesji Sejmiku Województwa Śląskiego IV kadencji [Record no. XXVI/12 of the 26th session of Silesian Voivodeship Regional Assembly of the 4th tenure], 17 September 2012, pp. 23-24; Protokól nr XXIX/2/12 z II posiedzenia XXIX sesji Sejmiku Województwa Śląskiego IV kadencji [Record no. XXIX/2/12 of the 2nd session of Silesian Voivodeship Regional Assembly of the 4th tenure], 20 December 2012, p. 52.

${ }^{39}$ MERCIK, Henryk. Komu zależy na Industriadziie?, accessed 2 April 2020, https://www.jaskolkaslaska.eu/2014/06/14/ komu-zalezy-na-industriadzie/.
} 
This new perspective resulted in another translocation of a wooden church to the Chorzów open-air museum. Thanks to the efforts of the politicians from the Silesian Autonomy Movement and the local Lutheran Church, an abandoned and ruined protestant chapel from Bobrek (a district of Bytom city) was relocated. This prefabricated building was produced in 1932 by the Christoph \& Unmack AG company from Niesky in Lusatia. It was reconsecrated in September 2017 on the occasion of the Year of Reformation that was announced on the initiative of the same political circle. The Upper Silesian voivodeship was the first of three voivodeships where the authorities decided on such an undertaking. ${ }^{40}$ The translocation of the protestant church which was, due to the place of its production, definitely connected with German culture, meant the modification of the open-air museum, which opened itself to the works of the industrial era. It also meant breaking the monopoly held by the existing meanings of wooden churches as a symbol of a homogeneously Polish and Catholic character of this region.

\section{Conclusions}

The history of the preservation and interpretation of wooden churches in Upper Silesia could be perceived as a process of transition from a paradigm of monument preservation to the paradigm of heritage as described by Gregory Ashworth. ${ }^{41}$ At the same time it proves the illusiveness of the conviction of the first paradigm's supporters that the selection of the objects intended for preservation for future generations was based on objective criteria, free from ideological connotations. Frantic efforts to stop the devastation of the village churches have been motivated since the very beginning by the meanings constructed on the ground of cultural nationalism understood-to quote Hutchinson-as a movement of "reformers in conservative dress", who "seek to use tradition to legitimate social innovation (...) and to rally modernists to the cause of building on indigenous traditions rather than of obliterating them". ${ }^{42}$ In the Prussian legal system the preservation of monuments was implemented as a social activity, supported by the governmental and provincial administration. Therefore a special role was played by the associations which perceived the past as the source of revival. The reforming intentions were clearly visible in the use of the wooden church initiated by the Schlesischer Bund für Heimatschutz at the Cemetery Art Exhibition in Wrocław in 1913.

The reinterpreting of the wooden church in the interwar Silesian Voivodeship resulted from the need to satisfy the deficits of the Polish tradition in the region that had remained outside Poland for a few hundred years. Representatives of the Polish elite who combined various social roles-experts, policy-makers, activists, artists, or priests—acted as the heritage "producers". ${ }^{43}$ In their narratives about the past, various different aspects were accentuated, emphasising the duration of either Polishness or religion; however, both themes fully integrated on a level of a standardising Catholic-national discourse. The wooden church was therefore used to

\footnotetext{
${ }^{40}$ WIECZOREK, Krzysztof. Kościół ewangelicki z Bytomia-Bobrka. Wybrane problemy konserwatorskie w obiekcie o charakterze tymczasowym wykonanym z materiałów nietrwałych i nietypowych. In: Rocznik Mužeum „,Górnoślaski Park Etnograficzny w Chorzonie”, Vol. 5, 2017, pp. 177-195; Nowe sycie zabytkowego kościoła, accessed 2 April 2020, https://www.jaskolkaslaska.eu/2017/10/12/nowe-zycie-zabytkowego-kosciola/.

${ }^{41}$ ASHWORTH, Gregory. Preservation, conservation and heritage. Approaches to the past in the present through the built environment. In: Asian Anthropology, Vol. 10, No. 1, 2011, pp. 1-18.

${ }^{42}$ HUTCHINSON, John. Re-interpreting cultural nationalism. In: Australian Journal of Politics and History, Vol. 45, No. 3, 1999, p. 404.

${ }^{43}$ GORZELIK, Drewniany kościół..., pp. 57-59.
} 
implement the paradigm described by Ashworth as a single-core model in which "society accepts the valid existence of only one set of common values, social norms and practices and ethnic cultural characteristics as legitimately determining the place identity". "A similarly oriented practice of heritage management also appeared in the German part of the region after the seizing of power by the national socialists. However, to construct the meanings, previously developed Volkist ideas were used, and unlike on the Polish side of the border, there were some divergences of opinion between experts on monument preservation and the decision-makers. ${ }^{45}$

The single-core model also remained in force after 1945. Yet the change of relationship between the state and the Church influenced the verification of the meanings constructed by the producers of the public heritage. A wooden church in an open-air museum has become one of many evidences of Polishness, besides the secular wooden architecture. But with losing its liturgical function it has lost the status of a monument of a living religiousnessits museification meant, in this case, the marginalisation of religion. Experts in monument preservation have mainly played the role of heritage producers. The state authorities were the direct consumers of the past and the indirect consumer was the society, however deprived of the possibility to articulate its needs freely. Conservators, ethnologists, art historians, and museum workers responded to the demands generated by the state concerning the need for legitimisation of the new borders, ahistorical administrative division, and distribution of power. Through meeting the state's expectations, these specialists were also able to achieve their own goals, which were formulated on the basis of the monument preservation paradigm.

The political changes at the end of the twentieth century caused the emergence of the new "stakeholders" of the heritage, namely the local governments, and, since 1999, also the provincial administrations, organisations of national minorities, and associations cultivating various ideas of the past. As a consequence the single-core model began to evolve towards the core + model, characterised by "the existence of a consensual core identity, the leitkultur or leading culture to which are added a number of distinctive minority cultural groups". ${ }^{46}$ At first this transformation did not have any conspicuous impact on the open-air museums in Upper Silesia. The exhibitions were not supplemented with artifacts connected with Germanic village language islands and with the protestant settlements or with the modernisation of Upper Silesian villages in the Prussian or German state. The crucial moment was an emergence of the ethnoregional party in the Silesian regional assembly. It called for heritage policy referring to the salad bowl model in which the "basic idea is that the diverse ingredients are brought together and collectively create a whole without losing their distinctive characteristics". ${ }^{47}$ A direct and permanent result of this policy was the transfer of the protestant church from Bobrek, yet it did not finish the dispute between the supporters of different social models.

The history of interpretation of the Upper Silesian wooden church shows several phenomena of a more general nature. Shifting borders in Central Europe and establishing new national states, often laying claim to the same regions, generated the need for legitimisation

\footnotetext{
${ }^{44}$ ASHWORTH, Gregory. Pluralizing the past: heritage policies in plural societies. In: Edinburgh Architectural Research Journal, Vol. 16, No. 1, 2007, pp. 14-15.

45 The conservation officer of the Upper Silesian Province, a Roman Catholic priest, Adolf Hadelt, distanced himself from the activities undertaken in the church in the City Park in Bytom (HADELT, Adolf (ed.). Deutsche Kulturdenkmäler in Oberschlesien. Jahrbuch der oberschlesischen Denkmalpflege nebst dem Bericht des Provinqialkonservators. Breslau: Ostdeutsche Verlagsanstalt, 1934, p. 170).

${ }^{46}$ ASHWORTH, Pluralizing..., p. 17.

${ }^{47}$ ASHWORTH, Pluralizing..., p. 21.
} 
manifested in the demand for heritage. Vernacular architecture, due to the conviction about its conservative character and hence about its roots in the ancient tradition, was a particularly appreciated cultural resource, used for proving settlement continuity as well as the rights to the disputable territory. The ethnographers, art historians, and conservators forming the nationalist elites and discourses, acting as experts in the preservation of vernacular architecture, were also involved in the production of the heritage for most of the last century. This dual role shows how fluid the border between both paradigms can be. The demand for socio-political meanings suppressed thinking about heritage in terms of economy. It was only with the transformations at the end of the twentieth century that the way was paved for these ideas. The monuments of the vernacular architecture started to be perceived as a touristic product as well as in terms of a place "identity dividend". The transfer of the protestant church to the open-air museum in Chorzów and its circumstances prove that the wooden church still plays a major role in the regional heritage policy.

\section{References}

Archive sources

Archive of the Opole Village Museum

- f. Pisma i notatki [Documents and notes], 1958-1971

- f. Dokumentacja specjalna. Inwentaryzacja—kościół drewniany, Zawada Książęca, powiat Racibórz [f. Special records. Inventory—wooden church, Zawada Książęca, Racibórz county]

Archive of Upper Silesian Ethnographic Park in Chorzów

- f. Notatki dotyczące opracowania planu koncepcyjnego skansenu śląskiego w Wojewódzkim Parku Kultury i Wypoczynku. Ramowe wytyczne osiedla muzealnego typu skansenowskiego w Wojewódzkim Parku Kultury i Wypoczynku [f. Notes regarding the development of the conceptual plan of the Silesian open-air museum in the Voivodeship Park of Culture and Recreation. Framework guidelines for the museum of the open-air type in the Voivodeship Park of Culture and Recreation]

Archdiocese Archives in Katowice

- f. Akta parafii pw. Trójcy Św. w Leszczynach. Budowy, 1926-1976 [f. Records of the Holy Trinity parish church in Leszczyny. Building, 1926-1976]

Archive of the Marshal Office of the Silesian Voivodeship

\section{Materials}

II Ogólno-Polski zjazd Konserwatorów w Warszawie w 1927 r. (Uchwały i rezultaty). In: Ochrona Zabytków Sztuki. Warszawa: Ministerstwo Wyznań Religijnych i Oświecenia Publicznego, 1930-31, pp. 356-361.

Bericht des Provinzial-Konservators der Kunstdenkmäler der Provinz Schlesien über die Tätigkeit vom 1. Januar 1900 bis 31. Dezember 1902 erstattet an die Provinzial-Kommission zur Erhaltung und Erforschung der Denkmäler Schlesiens. Breslau: Druck von Grass, Barth und Comp. (W. Friedrich), 1903.

Bericht des Provinzial-Konservators der Kunstdenkmäler der Provinz Schlesien über die Tätigkeit vom 1. Januar 1903 bis 31. Dezember 1904 erstattet an die Provinzial-Kommission zur Erhaltung und Erforschung der Denkmäler Schlesiens. Breslau: Druck von Grass, Barth und Comp. (W. Friedrich), 1905. 
Bericht des Provinzial-Konservators der Kunstdenkmäler der Provinz Schlesien über die Tätigkeit vom 1. Januar 1907 bis 31. Dezember 1908 erstattet an die Provinzial-Kommission zur Erhaltung und Erforschung der Denkmäler Schlesiens. Breslau: Druck von Grass, Barth und Comp. (W. Friedrich), 1909.

Bericht des Provinzial-Konservators der Kunstdenkmäler der Provinz Schlesien über die Tätigkeit vom 1. Januar 1913 bis 31. Dezember 1914 erstattet an die Provinzial-Kommission zur Erhaltung und Erforschung der Denkmäler Schlesiens. Breslau: Druck von Grass, Barth und Comp. (W. Friedrich), 1914.

Brakujący paciorek....In: Diiennik Zachodni, 29 September 1997, p. 6.

Józef - Robotnik. To nie tylko skansenowa atrapa. In: Diłiennik Zachodni, 21-23 June 1996, p. 3. Mercik, Henryk. Komu zależy na Industriadzie?, accessed 2 April 2020, https:/ / www.jaskolkaslaska. eu/2014/06/14/komu-zalezy-na-industriadzie/.

Na Śląsku Opolskim. In: Powstaniec, 1 May 1937, p. 23.

Nowe życie zabytkowego kościola, accessed 2 April 2020, https://www.jaskolkaslaska. eu/2017/10/12/nowe-zycie-zabytkowego-kosciola/.

Powstaje szlak architektury drewnianej, accessed 2 April 2020, https://www.slaskie.pl/ content/386_2002-04-17.

Świątynia znalazła swe miejsce. In: Gość Niedżielny, 12 October 1997, p. 16.

\section{Literature}

ASHWORTH, Gregory (2007). Pluralizing the past: heritage policies in plural societies. In: Edinburgh Architectural Research Journal, Vol. 16, No. 1, pp. 12-19. ISSN 0140-5039.

ASHWORTH, Gregory (2011). Preservation, conservation and heritage. Approaches to the past in the present through the built environment. In: Asian Anthropology, Vol. 10, No. 1, pp. 1-18. ISSN 21684227.

BURGEMEISTER, Ludwig - WiggerT, Ernst (1905). Die Holqkirchen und Holztürme der preussischen Ostprovinzen. Berlin: Verlag von Julius Springer.

CHOJECKA, Ewa (2016). A New Polyphony of Art and History. Painting Decoration of the Bolesław Szabelski Auditorium in the Karol Szymanowski Academy of Music in Katowice. In: Revitalization of the Historic Building of the Karol Symanowski Academy of Music in Katowice 1 March 2014 to 30 April 2016. Katowice: Akademia Muzyczna im. Karola Szymanowskiego, pp. 3-18, accessed 2 April 2020, http://rewitalizacjaeog.pl/images/download/EOG_AM_aula_ album.pdf

CUNO, Carl (1852). Zu den Skizzen von den alten Holzkirchen in Syrin, Lubom und Bosatz (bei Ratibor). In: Zeitschrift für Bawwesen. Berlin: Ernst \& Sohn, Vol. 2, No. 5/6, p. 212.

DOBOROWOLSKI, Tadeusz (1946). Najstarsze drewniane kościoły ślaskie jako znaki zamierzchłej pržeszłości. Katowice: Instytut Śląski.

DOBROWOLSKI, Tadeusz (1930). Zabytki sztuki województwa ślaskiego $i$ ich znaczenie dla nauki. Referat wygtoszony na XV Zjeździe Rady Konserwatorów w Katowicach 10 października 1930 r. Cieszyn: [n.p.].

GORZELIK, Jerzy (2017). Drewniany kościół na Górnym Śląsku jako miejsce pamięci (do 1945 roku). In: Studia Ślaskie. Seria Nowa, Vol. 81, pp. 49-64. ISSN 0039-3355.

GWIOŹDZIK, Marek - SONTAG, Magdalena (2008). Kościółek św. Wawraynnca. Światynia ijej dzieje w Knurowie i Chorzowie. Chorzów: Parafia św. Wawrzyńca. 
HADELT, Adolf (ed.) (1934). Deutsche Kulturdenkmäler in Oberschlesien. Jahrbuch deroberschlesischen Denkmalpflege nebst dem Bericht des Provinzialkonservators. Breslau: Ostdeutsche Verlagsanstalt.

HEINEVETTER, Franz (1927). Die Schrotholzkirche Mariae Himmelfahrt auf dem Hauptfriedhof in Geliwitz. In: Gleiwitzer Jahrbuch. Gliwice: Gesellschaft zur Förderung der Stadtbücherei Gleiwitz, 1927, pp. 185-186.

HUTCHINSON, John (1999). Re-interpreting cultural nationalism. In: Australian Journal of Politics and History, Vol. 45, No. 3, pp. 392-409. ISSN 0004-9522.

ILKOSZ, Jerzy (1997). „Schlesischer Bund für Heimatschutz” i Wystawa Sztuki Cmentarnej. In: Roczniki S ztuki Ślaskiej, Vol. 16, pp. 173-182. ISSN 0557-2231.

KLAUSSMANN, Anton Oskar (1911). Oberschlesien vor 55 Jahren und wie ich es wiederfand. Berlin - Breslau - Kattowitz - Leipzig: Phönix-Verlag.

KOSSINNA, Gustaf (1919). Die deutsche Ostmark ein Urbeimatboden der Germanen. Kattowitz: Gebruder Bohm.

KURNATOWSKA, Zofia - KURNATOWSKI, Stanisław (2002). Der Einfluss nationalistischer Ideen auf die mitteleuropäische Urgeschichtsforschung. In: PISKORSKI, Jan M. - HACKMANN, Jörg - JAWORSKI, Rudolf (ed.). Deutsche Ostforschung und polnische Westforschung im Spannungsfeld von Wissenschaft und Politik. Disziplinen im Vergleich. Osnabrück Poznań: fibre Verlag / Polskie Towarzystwo Przyjaciół Nauk, pp. 93-103. ISBN 83-7063-313-7.

LUCHS, Hermann (1856). Stilbezeichnung und Datierung einiger Kirchen Schlesiens preußischen und österreichischen Antheils. In: Zeitschrift des Vereins für Geschichte und Alterthum Schlesiens. Breslau: Joseph Max \& Komp, Vol. I, No. 2, pp. 298-303.

LUCHS, Hermann (1871). Die oberschlesischen Holzkirchen und Verwandtes (Mit Beiträgen von dem geistlichen Rathe Hrn. Weltzel und dem Vic.-Amts-Rathe Hrn. Knoblich). In: Schlesische Provinzial-Blätter (Rübezabl), Vol. 75/ N.S. 10, No. 3, pp. 109-121.

LUTSCH, Hans (1894). Verzeichnis der Kunstdenkmäler der Provinz Schlesien. Bd. IV, Die Kunstdenkmäler des Reg.-Bezirks Oppeln. Breslau: Verlag von Wilh. Gott. Korn.

LUTSCH, Hans (1905). Die Dorfkirche. In: SoHnrey, Heinrich (ed.). Kunst auf dem Lande. Ein Wegweiser für die Pflege des Schönen und des Heimatsinnes im deutschen Dorfe. Bielefeld-LeipzigBerlin: Velhagen \& Klasing, pp. 21-56.

MACHA, Simon (1925). Die Schrotholzkirche auf der Beuthener Promenade, ein kirchliches Museum. In: KASPERKOWITZ Karl - SALOMON D. - STEIN Erwin (ed.). Die deutsche Stadt Beuthen O/S. und ibre nächste Umgebung (Monographien deutscher Städte 15). Berlin Friedenau: Deutscher Kommunal-Verlag, pp. 129-132.

NADOLSKI, Przemysław (2012). Przedwojenne pomniki Bytomia i jego dzielnic. In: NADOLSKI, Przemysław - WIECZOREK, Edward (ed.). Ze spižu i granitu. Pomniki Bytomia. Bytom: Muzeum Górnośląskie, pp. 28-29. ISBN 9788388880285.

NOWOSIELSKA-SOBEL, Joanna (2013). Od ziemi rodzinnej ku ojczyźnie ideologicznej. Ruch ochrony stron ojczystych (Heimatschutz) ze szczególnym uwaglednieniem Ślaska (1871-1933). Wrocław: Wydawnictwo Uniwersytetu Wrocławskiego. ISBN 978-83-229-3380-0.

POLAK-SPRINGER, Peter (2018). Recovered Territory. A German-Polish Conflict over Land and Culture, 1919-89. New York - Oxford: Berghahn Books. ISBN 978-1-78533-814-4.

RYGUS, Piotr (2013). Muzeum na wolnym powietrzu w Katowicach (1929-1955). Idee, plany i realizacja. In: Rocznik Muzeum „Górnoślaski Park Etnograficzny w Chorzowie”, Vol. 1, pp. 83-90. ISSN 2353-2734. 
SMITH, Anthony D. (2003). Chosen Peoples: Sacred Sources of National Identity. Oxford: Oxford University Press. ISBN 978-0192100177.

SPEITKAMP, Winfried (1996). Die Verwaltung der Geschichte. Denkmalpflege und Staat in Deutschland 1871-1933. Göttingen: Vandenhoeck \& Ruprecht. ISBN 978-3525357774.

STÖRTKUHL, Beate (2013). Moderne Architektur in Schlesien 1900 bis 1939. Baukultur und Politik. München: R. Oldenbourg Verlag. ISBN 978-3486712087.

STRZYGOWSKI, Josef (1929). Die altslavische Kunst. Augsburg: Filser.

WIECZOREK, Krzysztof (2017). Kościół ewangelicki z Bytomia-Bobrka. Wybrane problemy konserwatorskie w obiekcie o charakterze tymczasowym wykonanym z materiałów nietrwałych i nietypowych. In: Rocznik. Muzeum „Górnoślaski Park Etnograficzny w Chorzowie”, Vol. 5, pp. 177-195. ISSN 2353-2734. 